\title{
UJI AKTIVITAS ANTIOKSIDAN FRAKSI DIETIL ETER DAUN BERUWAS LAUT (Scaevola taccada (Gaertn.) Roxb.) PADA TIKUS (Rattus norvegicus) YANG DIINDUKSI ALOKSAN DENGAN PARAMETER MDA
}

\author{
Sukmawati, Rahmawati, Firdaus \\ Fakultas Farmasi Universitas Muslim Indonesia \\ Email : sukmawatiarifin@gmail.com
}

\begin{abstract}
The research on the antioxidant activity test of dietil eter fraction from beruwas laut leaf (Scaevola taccada (Gaertn.) Roxb.) on diabetic rats (Rattus norvegicus) with $M D A$ indicator. This research was aimed to prove antioxidant activity of dietil eter fraction of beruwas laut (Scaevola taccada (Gaertn.) Roxb.) on diabetic rats (Rattus norvegicus) with MDA indicator. This research use 6 male rats were divided into 2 groups. Each groups consists of 3 male rats. All of rats on diabetic condition by alloxan induced $110 \mathrm{mg} / \mathrm{kg} \mathrm{BB}$ intraperitoneal injection. The control group has been given $\mathrm{Na}$ CMC 1\%, the fraction 3\% group has been given dietil eter fraction 3\%. Administration were orally until 7 days. At the end of research, all of rats were taked their blood for determined of absorbance at spektrofotometer $532 \mathrm{~nm}$ wave length. The result of the research showed that dietil eter fraction 3\% can decreased MDA absorbance of diabetic rats (Rattus norvegicus).
\end{abstract}

Key Word : Antioxidant, Scaevola taccada, MDA, Rattus norvegicus

\section{PENDAHULUAN}

Radikal bebas adalah atom atau senyawa yang kehilangan pasangan elektronnya.Sebagai contoh, atom oksigen $\left(\mathrm{O}_{2}\right)$ yang normal mempunyai 4 (empat) pasang elektron. Proses metabolisme seharihari yang merupakan proses biokimia yang menyebabkan terbentuknya radikal bebas yang bersifat sementara karena dengan cepat diubah menjadi senyawa yang tidak berbahaya bagi tubuh (Kumalaningsih, 2008). Diabetes mellitus adalah suatu keadaan gangguan metabolisme karbohidrat yang ditandai dengan kadar gula darah yang tinggi dan terdapat glukosa dalam urin (Glukosuria). Hiperglikemia ini dapat menyebabkan produksi Reactive OxygenSpecies (ROS) atau radikal bebas yang berlebihan dan akan memicu terjadinya stress oksidatif, yaitu suatu keadaan dimana jumlah radikal bebas yang diproduksi melebihi kapasitas tubuh untuk menangkalnya (wiryana, 2008). Dengan adanya paparan stress oksidatif, enzim 
Uji Aktivitas Antioksidan Fraksi Dietil Eter Daun Beruwas Laut Yang Diinduksi Aloksan Dengan Parameter MDA

Superokside Dismutase (SOD)

gunakan oleh masyarakat Pinrang sebagai antioksidan endogen akan Sulawesi Selatan dan mereka meningkat aktivitasnya untuk meredam stress oksidatif tersebut, yaitu dengan merubah anion superokside $\left(\mathrm{O}_{2}{ }^{-}\right)$menjadi hidrogen peroksida $\left(\mathrm{H}_{2} \mathrm{O}_{2}\right)$ dan oksigen $\left(\mathrm{O}_{2}\right)$, sehingga dapat melindungi sel-sel $\beta$ pankreas.Kerusakan oksidatif dapat juga diredam dengan menggunakan antioksidan eksogen yang berasal dari luar tubuh baik yang berbahan dasar kimia sintetik maupun bahan alam.

Beberapa tahun terakhir pemakaian obat tradisional dalam pengobatan semakin besar sejalan dengan bertambahnya sikap kritis masyarakat terhadap pemakaian bermacam-macam bahan kimia sintetik.Sementara pengujian dan penelitian secara ilmiah terhadap obat tradisional masih kurang sehingga pemakaiannya belum dapat dipertanggungjawabkan.

Indonesia memilikibanyak jenis tumbuhan yang diduga berkhasiat untuk pengobatan termasuk pengobatan diabetes mellitus dan telah digunakan secara turun-temurun karena selain efek sampingnya relatif kecil juga harga lebih ekonomis.Salah satu tanaman yang dimaksud yaitu daun Beruwas laut (Scaevola taccada (Gaertn.)Roxb.), tanaman ini telah di

menyebut tanaman ini sebagai Sawi laut.Sejauh mana pengaruh Beruwas laut (Scaevola taccada (Gaertn.) Roxb.) dalam penyembuhan diabetes belum diketahui secara pasti khususnya dalam upaya memperlambat dan meminimalkan kerusakan jaringan yang ditimbulkan oleh penyakit diabetes. Selain itu kandungan dari tumbuhan beruwas laut (Scaevola taccada (Gaertn.) Roxb.) adalah alkaloid, fenolik, saponin. Glikosid jenis scaevolin dan satu lagi jenis glikosid lain dari seluruh bagian tumbuhan ini.

Berdasarkan hasil penelitian yang telah dilakukan sebelumnya bahwa daun beruwas laut (Scaevola taccada (Gaertn.)Roxb.)dapat menurunkan kadar glukosa darah atau memiliki efek hipoglikemik (Intan N, 2012).

\section{METODE PENELITIAN}

\section{A. Alat dan Bahan}

Alat yang digunakan pada penelitian ini yaituAlat-alat gelas $\left(\right.$ Pyrex $\left.^{\circledR}\right)$, kanula, kuvet, pipa kapiler, spoit, seperangkat alat maserasi, seperangkat alat rotavapor, spektorofotometri Uvvis, seperangkat alat glukometer (One touch $^{\circledR}$ ), seperangkat alat 
sentrifugasi, tabung sentrifuge dan timbangan O'hauss (Camry ${ }^{\circledR}$ ).

Bahan yang digunakan pada penelitian ini yaitu aquadest, aloksan, asam klorida, asam asetat, Beruwas laut (Scaevola taccada (Gaertn.) Roxb.), dietil eter, EDTA, ketamin, n-butanol, $\mathrm{Na}-\mathrm{CMC}, \mathrm{NaCl}, \mathrm{Na}_{2} \mathrm{SO}_{4}, \quad$ TBA (Asam tiobarbiturat) dan TCA (Asam trikloro asetat).

\section{B. Prosedur Kerja}

\section{Penyiapan alat dan bahan}

Alat dan bahan disiapkan sesuai dengan kebutuhan penelitian yang akan dilaksanakan.

2. Pengambilan dan pengolahan sampel

Sampel Beruwas laut (Scaevola taccada (Gaertn.) Roxb.) diambil di kota Pinrang. Sampel kemudian dibersihkan dari kotoran yang melekat dengan menggunakan air mengalir lalu dikeringkan dengan cara diangin-anginkan. Setelah kering sampel dipotong-potong kecil, kemudian siap untuk diekstraksi dengan metode maserasi.

3. Preparasi ekstrak daun

\section{Beruwas laut}

a. Esktraksi dengan pelarut etanol

Sampel berupa Beruwas laut (Scaevola taccada (Gaertn.) Roxb.) sebanyak $\quad 300 \quad$ gr dimasukkan ke dalam wadah maserasi, lalu ditambahkan pelarut etanol $70 \%$, hingga simplisia tersebut terendam, dibiarkan selama 7 hari dalam bejana tertutup dan terlindung dari cahaya matahari langsung sambil diaduk secara periodik, setelah $7 \times 24$ jam dilakukan penyaringan dan ampasnya dimaserasi kembali dengan cairan penyari yang baru. Maserasi dilakukan sebanyak 3 kali dan diperoleh ekstrak etanol cair. Hasil penyarian yang diperoleh kemudian diuapkan.

b. Partisi dengan dietil eter

Ekstrak etanol kering yang diperoleh, diambil sebanyak 5 gram untuk diekstraksi dengan pelarut dietil eter dengan cara partisi cair-cair yaitu ekstrak etanol kering tersebut dimasukkan kedalam labu 
Erlenmeyer $250 \mathrm{ml}$, lalu ditambahkan sekitar $50 \mathrm{ml}$ dietil eter kemudian dikocok secara konstan berlawan arah jarum jam. Kemudian diletakkan secara vertikal, ditunggu sampai terjadi pemisahan larutan, dan lapisan bagian atas yang diambil. Proses partisi caircair ini dilakukan hingga pelarut dieil eter yang ditambahkanmenjadi bening. Ekstrak larut dietil eter dikumpulkan, pelarut diuapkan hingga diperoleh ekstrakdietil eter kering

4. Pembuatan aloksan 110 $\mathrm{mg} / \mathrm{kgBB}$

Sebanyak 2,7 gram aloksan ditambah larutan $\mathrm{NaCl}$ fisiologis $25 \mathrm{ml}$, dihomogenkan kemudian dicukupkan volumenya hingga $50 \mathrm{ml}$.

5. Pembuatan suspensi Na-CMC $1 \%$

Sebanyak $1 \mathrm{~g} \mathrm{Na}-\mathrm{CMC}$ dimasukkan sedikit demi sedikit kedalam $50 \mathrm{ml}$ air suling panas sambil diaduk dengan menggunakan pengaduk elektrik hingga terbentuk suspensi yang homogen, kemudian dicukupkan volumenya hingga $100 \mathrm{ml}$.

\section{Pembuatan TCA $10 \%$}

Sebanyak 10 gram asam trikloroasetat ditimbang lalu dilarutkan dengan sedikit aquadest, kemudian diencerkan sampai volume larutan menjadi $100 \mathrm{ml}$.

\section{Pembuatan $\mathrm{Na}_{2} \mathrm{SO}_{4} 2 \mathrm{~mol} / \mathrm{L}$}

Sebanyak 14,204 gram natrium sulfat ditimbang lalu dilarutkan dengan sedikit aquadest, kemudian diencerkan sampai volume larutan menjadi $50 \mathrm{ml}$.

8. Pembuatan TBA ( $2 \mathrm{~g} / \mathrm{l}$ dalam $2 \mathrm{~mol} / / \mathrm{Na}_{2} \mathrm{SO}_{4}$ )

Sebanyak $100 \mathrm{mg}$ asam tiobarbiturat ditimbang lalu dilarutkan dengan sedikit aquadest, kemudian diencerkan sampai volume larutan menjadi $50 \mathrm{mINa}_{2} \mathrm{SO}_{4}$.

\section{Pembuatan asam asetat $10 \%$}

Sebanyak $10 \mathrm{ml}$ asam asetat dilarutkan dengan sedikit aquadest kemudian diencerkan sampai volume larutan menjadi $100 \mathrm{ml}$.

\section{Pembuatan EDTA $10 \%$}

Sebanyak 10 gram EDTA ditimbang lalu dilarutkan dengan sedikit aquadest hingga homogen kemudian dicukupkan 
volumenya hingga $100 \mathrm{ml}$.

\section{Pembuatan suspensi fraksi dietil eter $3 \%$}

Ekstrak dietil eter daun beruwas laut (Scaevola taccada (Gaertn.) Roxb.) ditimbang sebanyak 3 gram, dimasukkan kedalam lumpang dan ditambahkan $\mathrm{Na}-\mathrm{CMC} \quad 1 \%$ sebanyak $100 \mathrm{ml}$ dan diaduk hingga merata.

\section{Perlakuan terhadap hewan uji}

Pada tahap ini akan diuji pengaruh konsentrasi ekstrak daun Beruwas laut (Scaevola taccada (Gaertn.) Roxb.) pada hewan uji. Sebanyak 6 ekor tikus jantan (Rattus norvegicus) umur 2-3 bulan dengan berat badan antara 200-300 gram dibagi menjadi 2 kelompok perlakuan, tiap perlakuan terdiri dari 3 ekor tikus. Sebelum perlakuan, tikus (Rattus norvegicus diadaptasikan selama 1 minggu dengan pemberian pakan dan air minum secara ad libitium. Perlakuan dimulai dengan tikus dipuasakan selama 8 jam dan selanjutnya diukur kadar glukosa darah awal dan diukur absorbansinya sebagai nilai MDA awal. Masing-masing tikus diinduksi aloksan dengan dosis $110 \mathrm{mg} / \mathrm{kg}$ BB secara intraperitoneal. Setelah 3 hari diukur kadar glukosa darah dan dihitung sebagai glukosa darah induksi dan diukur absorbannya sebagai nilai MDA induksi. Selanjutnya dilakukan perlakuan selama 7 hari adalah sebagai berikut:

a. Kelompok I (kontrol), yaitu tikus hanya diberi aloksan $110 \mathrm{mg} / \mathrm{kg}$ BB danNa-CMC $1 \%$

b. Kelompok II, yaitu tikus diberi aloksan $110 \mathrm{mg} / \mathrm{kg}$ BBdan fraksi dietil eter daun Beruwas laut 3\%

Selama penelitian, semua tikus diamati kadarglukosa darahnya setelah pemberian terapi fraksi. Pada akhir penelitian, semua tikusdiukur glukosa darahnya dan diambil darah untuk pemeriksaan MDA.

\section{Pengambilan darah hewan uji}

Proses pengambilan darah pada hewan uji tikus (Rattus norvegicus) dilakukan secara plexus retroorbitalis. Tikus diinjeksi ketamin dengan dosis $50 \mathrm{mg} / 10 \mathrm{ml}$ secara intra peritoneal. Kemudian pipa 
Uji Aktivitas Antioksidan Fraksi Dietil Eter Daun Beruwas Laut Yang Diinduksi Aloksan Dengan Parameter MDA

kapiler digoreskan pada medial canthus mata dibawah bola mata kearah foramen opticus. Pipa kapiler diputar sampai melukai plexus dan darah ditampung pada vial yang telah diberi EDTA.

\section{Analisis MDA}

Darah dikumpulkan dalam vial yang berisi larutan EDTA. Sebanyak $0,5 \mathrm{ml}$ darah dimasukkan kedalam tabung sentrifuge dan kemudian protein diendapkan dengan menambahkan 2,5 ml dari 200 $\mathrm{g} / \mathrm{L}$ asam trikloroasetat. Setelah itu disentrifuge pada $1000 \mathrm{rpm}$ selama 10 menit kemudian supernatant dipisahkan.
Endapan protein disuspensikan kembali dalam 2,5 $\mathrm{ml}$ asam asetat dan ditambahkan $3 \mathrm{ml}$ asam tiobarbiturat $(2 \mathrm{~g} / \mathrm{L}$ dalam $2 \mathrm{~mol} / \mathrm{L} \quad \mathrm{Na}_{2} \mathrm{SO}_{4}$ ). Campuran reaksi dipanaskan dalam waterbath selama 30 menit, kemudian didinginkan cepat dalam ice bath untuk menghentikan reaksi. Kemudian diekstraksi dengan menambahkan n-butanol sebanyak $4 \mathrm{ml}$ dan disentrifuge kembali pada 3000 rpm selama 10 menit. Hasil sentrifuge tersebut diukur absorbansinya pada spektrofotometri dengan panjang gelombang $532 \mathrm{~nm}$ (O'Haver TC, 1979).

\section{HASIL PENELITIAN}

Tabel 1. Hasil absorban MDA awal, induksi dan perlakuan pada tikus (Rattus norvegicus)

\begin{tabular}{|c|c|c|c|c|c|c|}
\hline Kontrol & $\begin{array}{c}\text { Glukosa darah } \\
\text { puasa } \\
\text { mg/dL }\end{array}$ & $\begin{array}{c}\text { Glukosa darah } \\
\text { induksi } \\
\text { mg/dL }\end{array}$ & $\begin{array}{c}\text { Glukosa darah } \\
\text { terapi } \\
\mathrm{mg} / \mathrm{dL}\end{array}$ & $\begin{array}{c}\text { Absorban } \\
\text { Awal }\end{array}$ & $\begin{array}{c}\text { Absorban } \\
\text { induksi }\end{array}$ & $\begin{array}{c}\text { Absorban } \\
\text { Na CMC } \\
1 \%\end{array}$ \\
\hline 1 & 78 & 125 & 371 & 0,008 & 0,009 & 0,056 \\
\hline 2 & 117 & 126 & 135 & 0,009 & 0,058 & 0,093 \\
\hline 3 & 88 & 125 & 132 & 0,005 & 0,041 & 0,097 \\
\hline \multicolumn{4}{|c|}{ TOTAL } & 0,021 & 0,108 & 0,246 \\
\hline \multicolumn{4}{|c|}{ Rata-rata } & 0,007 & 0,036 & 0,082 \\
\hline \multicolumn{7}{|c|}{ Pengukuran Absorban MDA Fraksi Dietil Eter Beruwas Laut 3\% } \\
\hline $\begin{array}{c}\text { Fraksi } \\
3 \%\end{array}$ & $\begin{array}{c}\text { Glukosa darah } \\
\text { puasa } \\
\text { mg/dL }\end{array}$ & $\begin{array}{c}\text { Glukosa darah } \\
\text { induksi } \\
\text { mg/dL }\end{array}$ & $\begin{array}{c}\text { Glukosa darah } \\
\text { terapi } \\
\text { mg/dL }\end{array}$ & $\begin{array}{l}\text { Absorban } \\
\text { Awal }\end{array}$ & $\begin{array}{l}\text { Absorban } \\
\text { induksi }\end{array}$ & $\begin{array}{l}\text { Absorban } \\
\text { fraksi } 3 \%\end{array}$ \\
\hline 1 & 99 & 129 & 85 & 0,005 & 0,042 & 0,017 \\
\hline 2 & 101 & 125 & 82 & 0,020 & 0,081 & 0,053 \\
\hline 3 & 84 & 126 & 85 & 0,002 & 0,040 & 0,002 \\
\hline \multicolumn{4}{|c|}{ TOTAL } & 0,027 & 0,163 & 0,072 \\
\hline \multicolumn{4}{|c|}{ Rata-rata } & 0,009 & 0,054 & 0,024 \\
\hline
\end{tabular}


Uji Aktivitas Antioksidan Fraksi Dietil Eter Daun Beruwas Laut Yang Diinduksi Aloksan Dengan Parameter MDA

\section{PEMBAHASAN}

Penelitian ini dilakukan untuk melihat aktivitas antioksidan daun beruwas laut (Scaevola taccada (Gaertn.) Roxb) terhadap kadar MDA tikus (Rattus norvegicus) yang diinduksi aloksan. Fraksi dietil eter daun beruwas laut (Scaevola taccada (Gaertn.) Roxb) diberikan dengan konsentrasi ekstrak 3\%.

Penelitian ini mengunakan daun beruwas laut (Scaevola taccada (Gaertn.) Roxb )karena berdasarkan penelitian yang telah dilakukan bahwa memiliki aktivitas antioksidan yang dapat meredam kerusakan oksidatif pada tikus yang diinduksi aloksan dengan menurunkan absorbansi MDAnya. Hewan coba tikus digunakan karena karakteristik genetik, biologi dan perilaku mereka sangat mirip dengan manusia, dan banyak gejala suatu penyakit pada kondisi manusia dapat direplikasi pada tikus. Tikus juga memiliki kekuatan fisik yang jauh lebih kuat dibanding mencit untuk pemberian fraksi selama 7 hari. Penelitian ini menggunakan tikus sebanyak 6 ekor dan dibagi menjadi 2 kelompok perlakuan. Tiap kelompok terdiri dari 3 ekor tikus, Kemudian semua tikus diinduksi aloksan 110 mg/kg BB intraperitoneal. Kelompok I diberi $\mathrm{Na}$ CMC 1\% dan kelompok II diberi fraksi dietil eter daun beruwas laut $3 \%$ selama 7 hari. Pada akhir penelitian semua tikus diambil darahnya untuk analisis MDA. Induksi aloksan dimaksudkan untuk membuat semua tikus diabetes mellitus karena aloksan bersifat toksisitas sehingga menyebabkan peroksidasi lipid padasel beta pankreas. Aloksan menghasilkan radikal aloksan dan radikal hidroksil $\left(\mathrm{OH}^{-}\right)$.

Analisis MDA digunakan karena merupakan analisis anti radikal bebas secara tidak langsung dan mudah dalam menentukan jumlah radikal bebas yang terbentuk. Penentuan aktivitas antioksidan daun beruwas laut (Scaevola taccada (Gaertn.) Roxb) dengan parameter MDA dilakukan dengan metode spektrofotometri yang menggunakan spektrofotometri UV-Vis. Metode ini merupakan metode yang paling banyak digunakan untuk mengukur keberadaan radikal bebas dan peroksidasi lipid, mempunyai kepekaan yang cukup tinggi, mudah diaplikasikan untuk berbagai sampel. Metode ini didasarkan pada reaksi antara kompleks MDA dengan TBA kemudian diukur pada spektrofotometer dengan panjang gelombang $532 \mathrm{~nm}$. 
Uji Aktivitas Antioksidan Fraksi Dietil Eter Daun Beruwas Laut Yang Diinduksi Aloksan Dengan Parameter MDA

Perbandingan MDA sebelum induksi aloksan, setelah induksi aloksan dan perlakuan antara kelompok kontrol dan kelompok fraksi dietil eter daun beruwas laut 3\% menggunakan uji one way anova. Rerata absorban MDA kelompok kontrol sebelum induksi aloksan adalah 0,007 dan rerata absorban MDA kelompok ekstrak dietil eter daun beruwas laut $3 \%$ sebelum induksi aloksan adalah 0,009. Uji perbandingan ini dilakukan menggunakan ujione way anova menunjukan bahwa tidak signifikan atau tidak ada perbedaan yang bermakna $(p>0,05)$. Hal ini berarti bahwa MDA pada kelompok kontrol dan kelompok fraksi dietil eter daun beruwas laut $3 \%$ sebelum induksi aloksan tidak memiliki perbedaan yang bermakna $(p>0.05)$, dengan ini maka penelitian dapat dilanjutkan untuk melihat pengaruhnya.

Rerata absorban MDA pada kelompok kontrol setelah induksi adalah 0,036 dan rerata absorban MDA pada kelompok fraksi dietil eter daun beruwas laut 3\% setelah induksi adalah 0,054. Hasil ini menunjukkan bahwa tidak signifikan atau tidak ada perbedaan yang bermakna ( $p>0,05)$, dengan ini maka penelitian dapat dilanjutkan untuk melihat pengaruhnya. Hal ini berarti bahwa MDA pada kelompok kontrol dan fraksi dietil eter daun beruwas laut 3\% setelah induksi tidak memiliki perbedaan yang bermakna $(p>0,05)$.

Sedangkan rerata absorban MDA pada kelompok kontrol Na-CMC $1 \%$ adalah 0,082 dan rerata absorban MDA pada kelompok fraksi dietil eter daun beruwas laut 3\% adalah 0,024 . Hasil ini menunjukkan bahwa terdapat perbedaan yang bermakna $(p<0,05)$. hal ini berarti bahwa MDA kelompok kontrol Na-CMC 1\% dan kelompok fraksi dietil eter daun beruwas laut 3\% terdapat penurunan MDA yang bermakna $(p<0,05)$.

Berdasarkan hasil penelitian diatas, terjadinya peningkatan MDA disebabkan terjadinya peroksidasi lipid pada membran sel beta pankreas akibat toksisitas aloksan. Selama mengalami metabolisme dalam tubuh, aloksan menghasilkan radikal aloksan dan radikal hidroksil $\left(\mathrm{OH}^{-}\right)$. Radikal hidroksil sangat toksik karena kemampuannya untuk berdifusi kedalam membrane sel selanjutnya bereaksi dengan membrane lipid menghasilkan produk MDA.

Menurunnya MDA menunjukkan adanya penghambatan terhadap peroksidasi lipid. Pemberian ekstak dietil eter daun beruwas laut dapat 
Uji Aktivitas Antioksidan Fraksi Dietil Eter Daun Beruwas Laut Yang Diinduksi Aloksan Dengan Parameter MDA

menurunkan MDA karena daun beruwas laut mengandung antioksidan. Hal ini sesuai dengan beberapa study yang menyatakan bahwa beruwas laut mengandung senyawa fenol yang dapat meredam aktivitas radikal bebas. Radikal bebas dapat menimbulkan peroksidasi lipid yang dapat diketahui dengan mengukur MDA.

Penelitian ini membuktikan bahwa fraksi dietil eter daun beruwas laut (Scaevola taccada (Gaertn.) Roxb) dapat menurunkan MDA pada tikus yang diinduksi aloksan.

\section{KESIMPULAN}

Dari hasil penelitian dapat disimpulkan bahwa pemberian fraksi dietil eter daun beruwas laut (Scaevola taccada (Gaertn.) Roxb) 3\% memberikan aktivitas antioksidan dengan menurunkan absorban MDA pada tikus (Rattus norvegicus) yang diinduksi aloksan.

\section{DAFTAR PUSTAKA}

American Diabetes Association. 2003. National Diabetes Fact Sheet. www. Diabetes.Org.

Ardiansyah, 2007. Antioksidan dan Peranannya Bagi Kesehatan, (Online), (http: //ardiansyah. multiply.com/14), Diakses15 Februari 2012).

Bird RP dan Draper HH. 1984. ComparativeStudies on Different Methods of Malon- aldehyde Determination Methods in Enzymology 105: 299-304pp.

Dipiro, T, Joseph., Talbert, L.R, 2008, “

Pharmacotherapy $A$ Pathophysiologic Approach" $7^{\text {th }}$. Mc Graw Hill Medical, United States.

Direktorat Jenderal Pengawasan Obat dan Makanan. 1986. Sediaan Galenik. Departemen Kesehatan RI, Jakarta.

Dalimartha S and Soedibyo M. 1998. Awet Muda. Dengan Tumbuhan Obatdan Diet Suplemen. TrubusAgriwidya. Jakarta.

Dyatmiko W, MH Santosa, and AF Hafid. 2000. Aktifitas Penangkapan Radikal Bebas Dalam SistemMolekuler dan Seluler Sari Air Rimpang Tanaman Obat Zingiberaceae. Lembaga Penelitian Universitas Airlangga. Pusat Penelitian Obat Tradisional Univ. Airlangga. Surabaya.

Gutteridge JMC, Halliwell B. 1996.Antioxidant in Nutritions Health and Disease. Oxford University Press. NewYork.

Halliwell B, Gutteridge JMC,.1999. Free Radicals IN Biology And Medicine. Oxford University Press. NewYork.

Harborne, J.B. 1987. Metode Fitokimia: Penuntun Cara Modern Menganalisis Tumubuhan Terjemahan $\mathrm{K}$. Padmawinata dan I. Sudiro. Penerbit ITB. Bandung 
Uji Aktivitas Antioksidan Fraksi Dietil Eter Daun Beruwas Laut Yang Diinduksi Aloksan Dengan Parameter MDA

Hudson, BJF. 1990. Food Antioxidants. Elsevier Applied Science. New York.

Howard C. Ansel. 2008. Pengantar Bentuk Sediaan Farmasi Edisi keempat. Penerbit Universitas Indonesia.

Kumalaningsih, S. 2007.Antioksidan Alami. Trubus Agrisarana, Surabaya.

Kim, J.A., J.A. Berlinerm, R.D. Natarajan dan J.L. Nadler. 1994. Evidence that glucose increase monocyte binding to human aortic endothelial cell. Diabetes 13.

Maysatria, Yamato. 2011. Scaevola taccada, (Online), (http://muherda.blogspot.com/ 2011/02/scaevolataccada.html , Di akses 21 Maret 2012).

Michele Woodley, M.D and Alison Whelan, M.D.1992. Manual of MedicalTerapeutics.Departme nt of Medicine. Washington University.

Ong, Hean Chooi. 2004. Tumbuhan liar: khasiat obatan \& kegunaan(Online),(http://www. scribd.com/doc/64909444/BioDivers-It-As Diakses 21 Maret 2012).

Rice-Evans, C., Anthony, T.D. 1991. Techniques In Free Radical Research. Elsevier. Pp $146,202$.

Suryohudoyo, P. 2000.Kapita Selekta IImu kedokteran Molekuler. CV Info Medika, Jakarta.
Suhartono, E., Fujiati, Aflanie, I. (2002). Oxygen toxicity by radiation andeffect of glutamicpiruvat transamine (GPT) activity rat plasma after vitamine $C$ treatmen, Diajukan padalnternatinal seminar on Environmental Chemistry and Toxicology, Yogyakarta.

Suharmiati. 2003. Pengujian Bioaktivitas Anti Diabetes Melitus Tumbuhan Obat. Majalah Cermin Dunia Kedokteran No.140.

Sunarni,T., (2005). Aktivitas Antioksidan Penangkap Radikal Bebas Beberapa kecambah Dari BijiTanaman Familia Papilionaceae, Jurnal Farmasi Indonesia 2 (2), 2001, 53-61.

Wardini, T.H. 2011. Medicinal and poisonous plants, (Online) (http://www.proseanet.org/flor akita/browser.php?docsid=74 7, Diakses 21 Maret2012)

Wiryana Made, 2008, Peranan Terapi Insulin Intensif Terhadap SOD, TNF- $\alpha$ dan IL-6 Pada Penderita Kritis Dengan Hiperglikemia, Denpasar; Pasca S3 Universitas Udayana

Zakaria FR. 1996. Peranan Zat Gizi dalamSistem Kekebalan Tubuh. Bul. Tek danlnd. Pangan 7:75-81 pp. 